\title{
Management of increased response to warfarin associated with decompensated heart failure in an outpatient family medicine clinic
}

\author{
Amanda Howard-Thompson*1, Erin Latendresse ${ }^{2}$, Erin Luippold ${ }^{3}$, Timothy H Self ${ }^{3}$ \\ ${ }^{1}$ Departments of Clinical Pharmacy and Family Medicine, University of Tennessee Health Science Center, USA \\ ${ }^{2}$ Veterans Affairs Tennessee Valley Healthcare System, Chattanooga Outpatient Clinic, USA \\ ${ }^{3}$ Department of Clinical Pharmacy, University of Tennessee Health Science Center, USA
}

Received: February 16, 2016

DOI: $10.5430 /$ crim.v3n2p18
Accepted: March 10, 2016

Online Published: March 22, 2016

\begin{abstract}
We report a 55-year-old patient with left ventricular heart failure and an ejection fraction of $<10 \%$ that was placed on warfarin therapy (42 mg/week) for the presence of a left ventricular thrombus. Thirty-nine days after hospital discharge, the patient presented with complaints of increased dyspnea over the previous week and required a wheelchair for mobility. The patient's weight had increased by $28 \mathrm{lbs}(13 \mathrm{~kg})$. As the patient's weight increased, his dose requirements for warfarin decreased resulting in an almost $30 \%$ reduction in his warfarin dose. Two months after the initiation of metolazone therapy, the patient lost $53 \mathrm{lbs}(24$ $\mathrm{kg}$ ) and his warfarin requirements increased eventually placing him on his original prescribed dose of $42 \mathrm{mg} /$ week. This case shows that if a patient's decompensated heart failure can be controlled with few exacerbations and close monitoring, they can be safely managed on warfarin in an outpatient setting.
\end{abstract}

Key Words: Warfarin, Decompensated heart failure, Outpatient

\section{INTRODUCTION}

Numerous factors have an effect on response to warfarin and other vitamin $\mathrm{K}$ antagonists, including age, dietary vitamin $\mathrm{K}$, drugs, pharmacogenetics, and disease states. ${ }^{[1-4]}$ Among several disease states that may alter response to warfarin is decompensated heart failure. ${ }^{[5-10]}$ Since the initial report of this effect nearly 70 years ago, other studies have also suggested enhanced response to warfarin in patients with heart failure exacerbations, but the possible association is not consistent. Various mechanisms are possible for the effect of heart failure exacerbations on response to warfarin, including hepatic dysfunction, decreased oxygen diffusion into hepatocytes due to edema, and reduced dietary vitamin $\mathrm{K}$ intake because of illness. ${ }^{[1-16]}$

We report the first case of the effects of decompensated heart failure on warfarin response in an outpatient family medicine clinic. While this effect has been seen clinically and documented in small studies in the outpatient setting there are usually confounding factors present (e.g., age, concomitant diseases and/or medications), which could also affect warfarin response in this patient population. This case is devoid of these confounding factors allowing for a clear picture the effect of this disease on warfarin response.

\footnotetext{
*Correspondence: Amanda Howard-Thompson; Email: amhoward@uthsc.edu; Address: University of Tennessee Health Science Center 881 Madison Ave Rm 217, Memphis, TN 38163, USA.
} 


\section{CASe presentation}

A 55-year-old black male with a past medical history remarkable for hypertension, left ventricular heart failure (ejection fraction $<10 \%$ ), left bundle branch block, and nonischemic cardiomyopathy referred for outpatient anticoagulation management secondary to left ventricular thrombus confirmed by echocardiogram. The thrombus was discovered while patient was hospitalized 11 days earlier for heart failure exacerbation. While inpatient, it was determined by the patient's cardiothoracic surgeon that the patient was a poor candidate for surgical intervention of thrombus removal due to his decompensated state and revascularization would not be of benefit due to his history of nonischemic cardiomyopathy. The patient was discharged from inpatient care on warfarin $6 \mathrm{mg}$ daily ( $42 \mathrm{mg} / \mathrm{week}$ ), furosemide $80 \mathrm{mg}$ twice daily, aspirin $81 \mathrm{mg}$ daily, carvedilol $6.25 \mathrm{mg}$ twice daily, digoxin $125 \mathrm{mcg}$ daily, and potassium chloride $20 \mathrm{mEq}$ daily. At the time of hospital discharge, the patient's international normalized ratio (INR) was therapeutic at 2.1 via venipuncture (goal INR 2-3) following 6 days of inpatient warfarin therapy. The following labs of significance obtained during his hospitalization are as follows: sodium 131 (134-144 $\mathrm{mmol} / \mathrm{L})$, potassium 3.2 (3.5-5.2 mmol/L), chloride 94 (97$108 \mathrm{mmol} / \mathrm{L})$, albumin $3.2(3.5-5.5 \mathrm{~g} / \mathrm{dl})$, total bilirubin 1.4 (0.0-1.2 mg/dl), alkaline phosphatase 154 (39-117 IU/L), red blood cells $5.72(3.77-5.28 \times 10 \mathrm{E} 6 / \mu \mathrm{l})$, mean corpuscular volume 77.7 (79-97 fl), mean corpuscular hemoglobin 25 (26.6-33 pg), red cell distribution width 17.3 (12.4\%-15.4\%), with all other values within normal limits.

Patient presented to a family medicine outpatient clinic 11 days after hospital discharge to see his primary care physician (PCP) and the pharmacist managed anticoagulation service for follow-up after hospitalization. The patient's weight at this visit was $224 \mathrm{lbs}(102 \mathrm{~kg})$. At this point, his PCP classified his heart failure as New York Heart Association (NYHA) functional class IV, however the patient was mobile without assistance from a wheelchair. Using the Roche CoaguChek ${ }^{\circledR}$ INR point-of-care monitor, the patient was found to have a supratherapeutic INR of 4 despite patient reporting one missed dose of warfarin the day prior and increasing consumption of vitamin $\mathrm{K}$ containing foods since hospital discharge. The patient's dose of warfarin was decreased 14\% to warfarin $6 \mathrm{mg}$ daily except $3 \mathrm{mg}$ on Monday and Friday ( $36 \mathrm{mg} /$ week).

Table 1 shows the time course of changes in the patient's weight, INR, and warfarin dose at subsequent visits. Warfarin doses were adjusted slightly at each visit to reflect patient's change in INR. As the patient's weight increased, his dose requirements for warfarin decreased. Thirty-nine days after hospital discharge, the patient presented with complaints of increased dyspnea over the previous week and required a wheelchair for mobility. The patient's weight had increased by $28 \mathrm{lbs}(13 \mathrm{~kg})$ since his initial outpatient anticoagulation visit. At this time, the patient's INR had increased to 5.4 via point-of-care testing which was confirmed by a venipuncture INR of 4.5. The patient reported compliance with current warfarin dose and denied recent variations in his vitamin $\mathrm{K}$ intake (3 servings/week) or medication regimen. This information resulted in holding the warfarin dose for two days then resuming therapy at dose of $3 \mathrm{mg}$ daily except $6 \mathrm{mg}$ on Monday, Wednesday, and Friday ( $30 \mathrm{mg} /$ week). The patient's cardiologist was notified regarding the patient's weight gain and INR increase despite decreasing warfarin dose by almost $30 \%$. The cardiologist then added metolazone $2.5 \mathrm{mg}$ daily and losartan $25 \mathrm{mg}$ daily to the patient's current medication regimen.

Table 1. Patient's anticoagulation and weight history

\begin{tabular}{llllll}
\hline $\begin{array}{l}\text { Days } \\
\text { Post-hospital } \\
\text { Discharge }\end{array}$ & $\begin{array}{l}\text { Warfarin Dosage } \\
\text { (mg/week) }\end{array}$ & INR $^{\# \mathbf{1}}$ & $\begin{array}{l}\text { Weight } \\
\text { (lbs) }\end{array}$ & $\begin{array}{l}\text { New Warfarin } \\
\text { Dosage (mg/week) }\end{array}$ & Comments \\
\hline 11 & 42 & 4 & 226 & 36 & Missed 6 mg dose \\
18 & 36 & 3.2 & 235 & 33 & Missed 3 mg dose \\
25 & 33 & 2.8 & 246.4 & 30 & Consistent VK ${ }^{\# 2}$ intake. Metolazone \\
39 & 30 & 5.4 & 253.1 & 30 & started \\
43 & 30 & $4.5 \mathrm{VP}^{\# 3}$ & 225 & 30 & Held 2 doses after previous visit \\
60 & 30 & 1.4 & 200 & 35 & No missed doses. Consistent VK intake \\
67 & 35 & 1.7 & 202 & 35 & No missed doses. Consistent VK intake \\
81 & 35 & 1.5 & 200 & 42 & No missed doses. Increased VK intake \\
\hline
\end{tabular}

${ }^{\# 1}$ Unless otherwise stated all international normalized ratio (INR) measurements were obtained via finger stick, using the Roche CoaguChek ${ }^{\circledR}$ INR point-of-care monitor; ${ }^{\# 2}$ Vitamin K; ${ }^{\# 3}$ Venipuncture (VP). 
Twenty-one days after the addition of metolazone to the patient's regimen, the patient's weight declined by $53 \mathrm{lbs}$ ( 24 $\mathrm{kg}$ ). The patient also had an improvement in NYHA functional class from class IV to III, as the patient reported the ability to perform activities of daily living without dyspnea. At this visit, the patient denied any missed doses of warfarin and stated consistency with vitamin K consumption. His INR on this date was subtherapeutic at $1.6 \mathrm{on} 30 \mathrm{mg}$ weekly. After multiple subtherapeutic INRs despite increasing warfarin dose the patient was eventually placed back on his original dose from hospital discharge of $42 \mathrm{mg} /$ week 2 months after starting metolazone therapy. The patient was then lost to outpatient follow-up due to subsequent hospital admissions secondary to cardiorenal syndrome and was eventually placed on hospice care due to his advance disease.

\section{DisCuSSION}

Decompensated heart failure has been reported as a potential factor associated with increased response to vitamin $\mathrm{K}$ antagonists for decades. ${ }^{[10]}$ Hylek et al. found in a retrospective cohort that elevated INRs returned to normal more slowly in decompensated heart failure patients receiving warfarin. ${ }^{[16]}$ Ripley and colleagues performed a small pilot prospective cohort in HF patients taking chronic warfarin therapy managed in an outpatient university based HF clinic and found moderate to severe levels of hypervolemia in HF patients resulted in overanticoagulation. ${ }^{[17]}$

To our knowledge, there have not been descriptions in the literature of individual heart failure patient over a period of several months that have received warfarin therapy during periods of disease stability as well as exacerbations. In addition, the patient described was not receiving any interacting medication and did not have concomitant interacting diseases allowing for a clear depiction of the effects of decompensated heart failure on warfarin response. Furthermore the patient's lab values show a correlation between his heart failure management and warfarin dose. Once our patient's heart failure symptoms were controlled, their warfarin dose was stabilized at a higher dose. This case shows that if a patient's heart failure can be controlled with few exacerbations, then a patient can be safely managed on warfarin in an outpatient setting. However, it should be emphasized that heart failure patients on vitamin $\mathrm{K}$ antagonists require more INR monitoring to ensure the patient stays within the therapeutic range. INR monitoring becomes especially important when there is a lack of stability in their weight due to their edematous state or with the addition of new medications or concomitant illnesses/diseases.

\section{CONFlicts OF INTEREST Disclosure}

The authors have declared no conflicts of interest.

\section{REFERENCES}

[1] Ageno W, Gallus AS, Wittkowsky A, et al. Oral anticoagulant therapy: Antithrombotic therapy and prevention of thrombosis, 9th ed: American College of Chest Physicians Evidence-Based Clinical Practice Guidelines. Chest. 2012; 141(2) (Suppl): e44s-e88s.

[2] Franco V, Polanczyk CA, Clausell N, et al. Role of dietary vitamin $\mathrm{K}$ intake in chronic oral anticoagulation: prospective evidence from observational and randomized protocols. Am J Med. 2004; 116 651-6. PMid:15121490 http://dx.doi.org/10.1016/j.amjme d. 2003.12 .036

[3] Petitti DB, Storm BL, Melmon KL. Prothrombin time ratio and other factors associated with bleeding in patients treated with warfarin. $\mathbf{J}$ Clin Epidemiol. 1989; 42: 759-64. http://dx.doi.org/10.1016 /0895-4356 (89) 90073-5

[4] Cotlove E, Vorzimer JJ. Serial prothrombin estimations in cardiac patients: diagnostic and therapeutic implications; use of dicumarol Ann Intern Med. 1946; 24: 648-65. PMid:21025284 http://dx.d oi .org/10.7326/0003-4819-24-4-648

[5] Self TH, Reaves AB, Oliphant CS, et al. Does heart failure exacerbation increase response to warfarin? A critical review of the literature. Curr Med Res Opin. 2006; 22: 2089-2094. PMid:17076968 http://dx.doi.org/10.1185/030079906X132479

[6] Anderson GM, Hull E. The use of Dicumarol as an adjunct to the treatment of congestive heart failure. South Med J. 1948; 41: 365-71. http://dx.doi.org/10.1097/00007611-194804000-00018
[7] Stats D, Davison S. The increased hypoprothombinemic effect of small dose of dicoumarol in congestive heart failure. Am J Med Sci. 1949; 218: 318-23. PMid:18137156 http://dx.doi.org/10.10 97/00000441-194909000-00011

[8] Wishart JH, Chapman CB. Dicoumarol therapy in congestive heart failure. N Engl J Med. 1948; 239: 701-4. PMid:18892580 http: //dx.doi.org/10.1056/NEJM194811042391902

[9] Penning-van Beest FJ, van Meegan E, Rosendaal FR, et al. Characteristics of anticoagulant therapy and comorbidity related to overanticoagulation. Thromb Haemost. 2001; 86: 569-74. PMid:11522005

[10] Visser LE, Bleumink GS, Trienekens PH, et al. The risk of overanticoagulation in patients with heart failure on coumarin anticoagulants. Br J Haematol. 2004; 127: 85-89. PMid:15384981 http://dx.doi.org/10.1111/j.1365-2141.2004.05162.x

[11] Le Counteur DG, McLean AJ. The aging liver. Drug clearance and an oxygen diffusion barrier hypothesis. Clin Pharmacokinet. 1998; 34: 359-73.

[12] Killip T, Payne M. High serum transaminase activity in heart disease. Circulation. 1960; 21: 646-60. PMid:14409072 http://dx.doi.o rg/10.1161/01. CIR.21.5.646

[13] Reisner EH, Norman J, Field W, et al. The effect of liver dysfunction on the response to dicoumarol. Am J Med Sci. 1949; 217: 445-7. PMid:18115159 http://dx.doi.org/10.1097/00000441-194 904000-00013

[14] Carr JG, Stevenson LW, Walden JA, et al. Prevalence and hemodynamic correlates of malnutrition in severe congestive heart failure 
secondary to ischemic or idiopathic dilated cardiomyopathy. Am J Cardiol. 1989; 63: 709-13. http://dx.doi.org/10.1016/000 2-9149(89) 90256-7

[15] Anker SD, Ponikowski P. Wasting as independent risk factor for mortality in chronic heart failure. Lancet. 1997; 349: 1050-3. http://dx.doi.org/10.1016/S0140-6736(96) 07015-8

[16] Hylek EM, Regan S, Go AS, et al. Clinical predictors of prolonged delay in return of the international normalized ratio to within the therapeutic range after excessive anticoagulation with warfarin. Ann Intern Med. 2001; 135: 393-400. PMid:11560452 http://dx.doi . org/10.7326/0003-4819-135-6-200109180-00008

[17] Ripley TL, Harrison D, Germany RE, et al. Effect of heart failure exacerbations on anticoagulation: A prospective, observational, pilot cohort study. Clin Ther. 2010; 32: 506-14. PMid:20399987 http://dx.doi.org/10.1016/j.clinthera.2010.03.001 